\title{
ANALISIS TINGKAT KESEHATAN BANK DILIHAT DARI STANDAR NON PERFORMING LOAN (NPL) PADA PT. BANK PERKREDITAN RAKYAT RAGA DANA SEJAHTERA CABANG PADANG
}

\author{
Yori Qalbi Khairi, Ratna Widayati \\ Akademi Keuangan Perbankan "Pembangunan" Padang \\ yoriqalbi1306@gmail.com
}

\begin{abstract}
This study aims to determine the level of bank health at PT. BPR Raga Dana Sejahtera in the Padang branch by using non-pefoming loan standards in 20152017, the impact of non-performing loans on company profits in 2015-2017, efforts made to overcome non-performing loans at PT. BPR Raga Dana Sejahtera Padang branch in 2015-2017. Data was collected using interviews and documentation. Data were analyzed using case study analysis with a quantitative approach. The results showed that the classification of the Bank's health level there are four categories, namely: healthy, healthy enough, less healthy, and unhealthy. the impact of non-performing loans to the Bank is the decline in profits, disruption of cash turnover, reduced level of bank soundness, reduced bank capital, and decreased public confidence. efforts made to overcome problem loans at PT. BPR Raga Dana Sejahtera Padang branch is a restructuring, rescheduling, foreclosure guarantee, and write off loans (write off receivables).
\end{abstract}

Keywords: Non Performing Loan (NPL).

\section{PENDAHULUAN}

Dunia perbankan merupakan salah satu institusi yang sangat berperan penting dalam bidang perekonomian suatu Negara (khususnya dibidang pembiayaan, perekonomian dan pembangunan).

Perbankan adalah segala sesuatu yang menyangkut tentang bank, kelembagaan, kegiatan usaha, serta cara dan proses dalam melaksanakan kegiatan usahanya.

Undang-Undang RI No. 10 Tahun 1998 tentang perbankan pasal 1 ayat 3 bahwa bank adalah suatu badan usaha yang berfungsi menghimpun dana dari masyarakat dalam bentuk simpanan dan menyalurkannya kepada masyarakat dalam bentuk kredit dan atau bentuk-bentuk lainnya dalam rangka meningkatkan taraf hidup rakyat banyak.

Dilihat dari segi fungsinya, bank dibagi menjadi dua yaitu Bank Umum dan Bank perkreditan Rakyat Raga Dana Sejahtera.

Pada zaman sekarang ini Bank Perkreditan Rakyat (BPR) memiliki pasar tersendiri di masyarakat. Pada umumnya masyarakat yang mempunyai usaha kecil menengah cenderung memilih Bank Perkreditan Rakyat (BPR) sebagai tempat meminjam uang untuk mengembangkan usaha dengan bunga kredit kecil dan prosedur peminjamannya lebih mudah. 
Bank Perkreditan Rakyat Raga Dana Sejahtera merupakan salah satu BPR di daerah Sumatra Barat, tepatnya di Kota Padang yang berperan memberikan kontribusi aktif bagi keberhasilan pelaksanaan pembangunan khususnya di bidang penyediaan modal bagi masyarakat dalam bentuk kredit.

Dalam pemberian kredit bank memiliki resiko salah satunya adalah tidak terbayar kembali pinjaman dari nasabah dan hal tersebut dapat mempengaruhi tingkat kesehatan bank yang disebut juga dengan Non Peforming Loan (NPL).

Non Performing Loan merupakan salah satu indikator kesehatan asset suatu bank. Indikator tersebut berupa resiko keuangan pokok yang mampu memberikan informasi penilaian atas kondisi permodalan, rentanilitas, risiko kredit, risiko pasar serta likuiditas.

Berdasarkan Surat Edaran Bank Indonesia No.6/23/DPNP tanggal 31 Mei 2004, penilaian tingkat kesehatan bank merupakan penilaian kualitatif atas berbagai aspek yang berpengaruh terhadap kondisi atau kinerja suatu bank melalui penilaian aspek permodalan, kualitas asset, manajemen, rentabilitas, likuiditas dan sensitivitas terhadap resiko pasar.

Kesehatan Bank Perkreditan Rakyat adalah suatu bentuk penilaian konsumen atau masyarakat terhadap tingkat perkembangan suatu bank yang nantinya pengaruh kepada keinginan masyarakat untuk bergabung pada bank tersebut. Bank yang sehat dijadikan sebagai patokan oleh masyarakat bahwa bank tersebut mampu berkembang dan dapat bersaing, serta mampu bertahan pada masanya.

Penggolongan tingkat kesehatan bank dibagi dalam empat kagetori yaitu: sehat, cukup sehat, kurang sehat, dan tidak sehat.

Dari uraian diatas maka penulis tertarik untuk untuk meneliti dan membahasnya dalam Tugas Akhir ini dengan judul "Analisis Tingkat Kesehatan Bank Dilihat Dari Standar Non Performing Loan (Npl) Pada PT. Bank Perkreditan Rakyat Raga Dana Sejahtera Cabang Padang".

Berikut ini jumlah kredit bermasalah yang terjadi pada PT. Bank Perkreditan Rakyat RDS Cabang Padang tiga tahun terakhir dapat dilihat pada tabel dibawah ini:

\section{Tabel 1}

Total Kredit Dan Kredit Bermasalah

Pada Bank Perkreditan Rakyat ( BPR ) RDS Cabang Padang Periode 2015-2017

( Dalam Rupiah )

\begin{tabular}{|c|c|c|}
\hline Tahun & Total Kredit & Jumlah Kredit Bermasalah \\
\hline 2015 & Rp. 11.765 .946 & Rp. 229.001 \\
\hline 2016 & Rp. 10.690 .721 & Rp. 1.278 .457 \\
\hline 2017 & Rp. 10.166 .174 & Rp. 1.949 .082 \\
\hline Total & Rp. 32.622 .841 & Rp. 3.526.540 \\
\hline
\end{tabular}

Sumber: BPR RDS Cabang Padang, data diolah

Berdasarkan table 1 diatas terlihat jumlah kredit pada tahun 2015 sebesar 229.001 dan pada tahun 2016 mengalami kenaikan sebesar 1.278.457, 
pada tahun selanjutnya yaitu tahun 2017 jumlah kredit bermasalah juga mengalami kenaikan yang cukup tinggi sebesar 1.949.082.

Dari uraian diatas maka penulis tertarik untuk untuk meneliti dan membahasnya dalam Tugas Akhir ini dengan judul "Analisis Tingkat Kesehatan Bank Dilihat Dari Standar Non Performing Loan (Npl) Pada PT. Bank Perkreditan Rakyat Raga Dana Sejahtera Cabang Padang”.

\section{Rumusan Masalah}

Berdasarkan uraian latar belakang tersebut, maka yang menjadi perumusan masalah adalah "Bagaimana tingkat kesehatan bank pada PT. Bank Perkreditan Rakyat Raga Dana Sejahtera Cabang Padang di lihat dari standar NPL.

\section{Tujuan Penelitian}

Tujuan penelitian ini adalah untuk mengetahui bagaimana tingkat kesehatan bank PT. Bank Perkreditan Rakyat Raga Dana Sejahtera Cabang Padang dengan menggunakan metode NPL selama periode tahun 2015, 2016 dan 2017.

\section{METODE PENELITIAN}

\section{Metode Pengumpulan Data}

1) Studi Kepustakaan (Library Research)

Penelitian ini dilakukan dengan cara mempelajari buku- buku, makalahmakalah, artikel, bacaan laporan dan publikasi yang berhubungan dengan objek penelitian.

2) Studi Lapangan (Field Research)

Peninjauan langsung ke objek penelitian yang dipilih yaitu dengan mewawancarai pihak- pihak yang berkepentingan seperti perusahaan dan instansi yang terkait.

\section{Metode Analisa Data}

Adapun metode analisa data yang digunakan adalah metode kualitatif yang bersifat deskriptif. Metode kualitatif merupakan metode yang dilakukan untuk mendapatkan informasi terkait melalui wawancara terhadap perusahaan dan metode deskriptif yang bertujuan untuk memberikan gambaran lengkap mengenai kejadian yang terjadi di PT. Bank Perkreditan Rakyat Raga Dana Sejahtera Cabang Padang.

\section{ANALISA DAN PEMBAHASAN Pengertian Kesehatan Bank}

Menurut (Spica \& Herdinigtyas, 2002) kesehatan bank merupakan kemampuan suatu bank dalam menjalankan kegiatan operasionalnya dan memenuhi kewajiban sesuai dengan peraturan perbankan. Sedangkan tingkat kesehatan bank adalah hasil penilaian kualitatif atas berbagai aspek yang berpengaruh terhadap kondisi atau kinerja suatu bank melalui penilaian faktor Capital (modal), Asset (aktiva), Management (manajemen), Earning (rentabilitas), dan Liquidity (likuiditas). 


\section{Pengertian Non Peforming Loan (NPL)}

Menurut (Dwihandayani, 2016) Non performing loan (NPL) adalah salah satu indikator kunci untuk menilai kinerja fungsi bank, karena NPL yang tinggi adalah indikator gagalnya bank dalam mengelola bisnis antara lain timbul masalah likuiditas (ketidakmampuan membayar pihak ketiga), rentabilitas (hutang tidak dapat ditagih), dan solvabilitas (modal berkurang). Laba yang merosot adalah salah satu imbasnya karena praktis bank kehilangan sumber pendapatan di samping harus menyisihkan pencadangan sesuai kolektibilitas kredit. NPL mencerminkan juga risiko kredit, semakin tinggi tingkat NPL maka semakin besar pula risiko kredit yang ditanggung oleh pihak bank. Besarnya NPL menjadi salah satu penyebab sulitnya perbankan dalam menyalurkan kredit

\section{Penyebab Terjadinya Kredit Bermasalah}

a. Faktor-faktor Intern (Managerial Factor)

Adalah faktor-faktor yang ada dalam diri perusahaan sendiri.

b. Faktor-faktor Ekstern

Adalah faktor-faktor yang berasal dari luar perusahaan

\section{Pengertian Analisa Kredit}

Menurut (Savitri, 2014) persetujuan kredit ditentukan dari hasil analisis kredit. Kredit yang disetujui adalah kredit yang layak, telah sesuai dengan kebijakan dengan prosedur pemberian kredit, tidak menyimpang dari ketentuanketentuan limit kredit dan ketentuan pemerintah, telah dipertimbangkan mengenai keamanan kreditnya, dan diputus sesuai dengan kewenangan memutus kredit.

Hal yang perlu diperhatikan dalam menganalisis kredit yaitu nasabah harus memenuhi prinsip 5C, 7P, dan 3R yaitu sebagai berikut:

Penilaian berdasarkan asas $5 \mathrm{C}$ sebagai berikut:
a. Character
b. Capacity
c. Collateral
d. Condition of Economy
e. Condition of Economy

Penilaian berdasarkan asas $7 \mathrm{P}$ dapat dilihat sebagai berikut:

a. Personality (kepribadian)

b. Party

c. Purpose

d. Prospect

e. Payment

f. Profitability

g. Protection

Penilaian yang berdasarkan atas asas $3 \mathrm{R}$ terdiri dari:
a. Returns
b. Repayment
c. Risk Bearing Ability 


\section{Pengertian Kolektibilitas Kredit}

Kolektibilitas kredit merupakan keadaan pembayaran pokok atau angsuran pokok dan bunga kredit yang dibayarkan oleh nasabah pengguna fasilitas pinjaman dana (kredit).

Terdapat beberapa kategori kualitas kredit calon debitur, yakni meliputi:

a. Lancar

Yaitu debitur selalu bayar hutang tepat waktu atau bisa dikatakan kredit lancer (peforming loan),

b. Dalam Perhatian Khusus (DPK)

Debitur mengalami penunggakan pembayaran angsuran atau utang dari 1-90 hari.

c. Kredit Kurang Lancer

Debitur mengalami penunggakan pembayaran angsuran atau utang dari 91120 hari.

d. Diragukan

Debitur mengalami penunggakan pembayaran utang dari 121-180 hari.

e. Macet

Debitur mengalami penunggakan pembayaran utang lebih dari 180 hari.

Analisis Tingkat Kesehatan Bank Dilihat Dari Standar Non Performing Loan (NPL)

Untuk mengukur tingkat kesehatan keuangan bank dapat diketahui dari analisa standar NPL. Metode ini digunakan untuk mengukur sejauh mana penurunan yang terjadi dalam total aktiva yang bisa ditutupi dari pembayaran kredit yang diterima.

Berdasarkan Data Perkembangan Total Kredit dan Non Performing loan (NPL) PT. Bank Perkreditan Rakyat Raga Dana Sejahtera Cabang Padang dapat dilihat bahwa :

Tabel 2

Perkembangan Total Kredit dan Non Performing Loan NPL PT. Bank Perkreditan Rakyat Raga Dana Sejahtera Cabang Padang

Tahun 2015-2017

\begin{tabular}{|c|c|c|l|c|}
\hline Tahun & Total Kredit & $\begin{array}{c}\text { Perubahan } \\
\text { \% }\end{array}$ & $\begin{array}{c}\text { Kredit } \\
\text { Bermasalah }\end{array}$ & $\begin{array}{c}\text { Perubahan } \\
\text { \% }\end{array}$ \\
\hline $\mathbf{2 0 1 5}$ & Rp. 11.659.889 & - & Rp. 299.001 & - \\
\hline $\mathbf{2 0 1 6}$ & Rp. 10.500 .321 & 10,50 & Rp. 1.278 .459 & 3,28 \\
\hline $\mathbf{2 0 1 7}$ & Rp. 9.594 .213 & 9,59 & Rp. 1.949 .082 & 3,49 \\
\hline
\end{tabular}

Sumber: PT. Bank Perkreditan Rakyat Raga Dana Sejahtera Cabang Padang.

Dari tabel dapat diketahui total kredit maupun non performing loan (NPL) tahun 2015 sebesar Rp. 11.659.889, Perubahannya masih kosong dikarenakan tahun dasar, pada tabel kredit bermasalah tahun tersebut sebesar 299.001 dengan perubahan juga masih kosong karena tahun dasar. 
Pada tahun 2016 total kredit mengalami sedikit penurunan sebesar Rp. 10.500.321, sehingga terjadi perubahan 10,50\%, dengan jumlah kredit bermasalah mengalami peningkatan sebesar 1.278 .459 dengan perubahan $3,28 \%$

Pada tahun 2017 total kredit juga mengalami penurunan sebesar Rp. 9.594.213 dengan perubahan yang mengalami penurunan sebesar 9,59\%, sedangkan kredit bermasalah mengalami peningkatan sebesar 1.949 .082 dan perubahan sebesar $3,49 \%$.

Jadi dari tabel 3.1 diatas dapat disimpulkan bahwa perubahan terhadap kredit bermasalah yang paling besar yaitu di tahun 2016 dengan persentase 3,49\%. Dengan demikian Non Performing Loan (NPL) dapat dijabarkan melalui rumus dibawah ini :

$$
\begin{aligned}
& \text { Non Performing Loan (NPL) } \\
& \text { Tahun } 2015 \\
& \text { NPL }=\text { Total Non Performing Loan } \times 100 \% \\
& \text { Total Kredit } \\
& =\frac{299.001}{11.659 .889} \times 100 \% \\
& =0,0256 \%
\end{aligned}
$$

Tahun 2016

NPL $=$ Total Non Performing Loan $\times 100 \%$

$$
\text { Total Kredit }
$$

$$
\begin{aligned}
& =\frac{1.278 .457}{10.500 .321} \times 100 \% \\
& =0,1217 \%
\end{aligned}
$$

Tahun 2017

$$
\begin{aligned}
\mathrm{NPL} & =\frac{\text { Total Non Performing Loan }}{\text { Total Kredit }} \times 100 \% \\
& =\frac{1.949 .082}{9.594 .213} \times 100 \% \\
& =0,2031 \%
\end{aligned}
$$

Non Performing Loan (NPL) pada PT. Bank Perkreditan Rakyat Raga Dana Sejahtera Cabang Padang pada tahun 2015 nilainya cukup baik 0,0256\%, karena Non Performing Loan (NPL) yang baik adalah Non Performing Loan (NPL) yang memiliki nilai dibawah $5 \%$.

Non Performing Loan (NPL) pada PT. Bank Perkreditan Rakyat Raga Dana Sejahtera Cabang Padang pada tahun 2016 nilainya cukup baik 0,1217\%, karena Non Performing Loan (NPL) yang baik adalah Non Performing Loan (NPL) yang memiliki nilai dibawah 5\%.

Non Performing Loan (NPL) pada PT. Bank Perkreditan Rakyat Cabang Padang pada tahun 2017 nilainya cukup baik 0,2031\%, karena Non Performing 
Loan (NPL) yang baik adalah Non Performing Loan (NPL) yang memiliki nilai dibawah $5 \%$.

Dari analisa diatas dapat di simpulkan bahwa nilai NPL tahun 2015: 0,0256\%, tahun 2016: 0,1217\%, dan tahun 2017: 0,2031\%. Artinya kemampuan PT. Bank Perkreditan Rakyat Raga Dana Sejahtera Cabang Padang tahun 2015 memperoleh hasil yang cukup baik dari total kredit lancar yang disalurkan oleh bank kepada nasabah.

Dengan melihat data diatas maka dapat dilihat eveluasi rata-rata industri seperti tabel dibawah ini.

\section{Tabel 3}

Evaluasi rata- rata industri

PT. Bank Perkreditan Rakyat Raga Dana Sejahtera Cabang Padang

Tahun 2015-2017

\begin{tabular}{|c|c|c|c|c|c|c|c|}
\hline Rasio & $\begin{array}{c}\text { Rata-Rata } \\
\text { Industri }\end{array}$ & $\begin{array}{c}\text { Tahun } \\
\mathbf{2 0 1 5}\end{array}$ & Evaluasi & $\begin{array}{c}\text { Tahun } \\
\mathbf{2 0 1 6}\end{array}$ & Evaluasi & $\begin{array}{c}\text { Tahun } \\
\mathbf{2 0 1 7}\end{array}$ & Evaluasi \\
\hline NPL & $<5 \%$ & 0,0256 & Sehat & 0,1217 & Sehat & 0,2031 & Sehat \\
\hline
\end{tabular}

Sumber: data diolah

Dilihat dari table di atas rata-rata industry non peforming loan (NPL) PT. Bank Perkreditan Rakyat Raga Dana Sejahtera Cabang Padang di bawah 5\% yaitu tahun 2015 sebesar 0,0256, tahun 2016 sebesar 0,1217 dan tahun 2017 sebesar 0,2031. Dapat di simpulkan bahwa matrik kriteria penilaian berdasarkan ketentuan Bank Indonesia adalah bank tersebut tergolong sehat karena NPL $<5$.

\section{Simpulan}

Non Peforming Loan (NPL) PT. Bank Perkreditan Rakyat Raga Dana Sejahtera Cabang Padang tahun 2015-2017 berada dibawah 5\% (tahun 2015 sebesar 0,0256, tahun 2016 sebesar 0,1217 dan tahun 2017 sebesar 0,2031). Dan jika dilihat dari Peraturan Bank Indonesia Nomor 6/10/PBI/2004 tentang sistem penilaian tingkat kesehatan bank, maka PT. Bank Perkreditan Rakyat Raga Dana Sejahtera Cabang Padang tahun 2015 sampai dengan 2017 dapat dikategorikan sebagai bank sehat.

\section{Saran}

1. Internal Bank hendaknya dapat memberikan pelayanan maksimal kepada nasabah dalam meningkatkan promosi untuk menarik minat masyarakat melakukan hubungan dengan Bank baik sebagai nasabah penabung maupun sebagai nasabah peminjam.

2. Untuk menambah kelancaran dalam pengelolaan kredit pada PT. Bank Perkreditan Rakyat Raga Dana Sejahtera Cabang Padang sebaiknya didukung dengan teknologi perbankan seperti perangkat komputer yang praktis dan efisien, serta teknologi perbankan yang baru.

3. Untuk mengantisipasi terjadinya kredit bermasalah sebaiknya Bank meningkatkan monitoring dan pengawasan terhadap kredit yang telah 
diberikan kepada nasabah baik mengenai manajemen maupun keadaan usaha debitur.

\section{UCAPAN TERIMA KASIH}

Penulis ucapkan puji dan syukur atas kehadirat-Nya, yang telah melimpahkan rahmat dan hidayah kepada penulis. Penulis ingin mengucapkan terima kasih yang tak terhingga atas bimbingan Ibu $\mathrm{Hj}$.Ratna Widayati, $\mathrm{SH}, \mathrm{MH}$ yang telah memberikan motivasi, masukan-masukan yang bermanfaat bagi penulis dan terima kasih untuk teman-teman atas semangat dan dukungannya dalam pembuatan artikel ini. Akhir kata penulis ucapkan terima kasih, semoga apa yang penulis tuangkan dalam karya kecil ini memberikan manfaat terutama bagi saya sendiri selaku penulis. Amin ya Rabbal'alamin.

\section{DAFTAR PUSTAKA}

Badria, M., \& Marlius, D. (2019). Analisis Rasio Likuiditas Pada PT. Bank Perkreditan Rakyat (BPR) Lengayang. https://doi.org/10.31219/osf.io/esvb7

Dwihandayani, D. (2016). ANALISIS KINERJA NON PERFORMING LOAN ( NPL ) PERBANKAN DI INDONESIA DAN FAKTOR-FAKTOR YANG MEMPENGARUHI NPL. 100, 265-274.

Ekonomika, F., Bisnis, D. A. N., \& Diponegoro, U. (2014). Kredit Bermasalah Pada Bank Umum.

Fitri, H. Y., \& Marlius, D. (2019). Analisis Rasio Likuiditas Pada PT. Bank Perkreditan Rakyat (BPR) Nagari Kasang. https://doi.org/10.31219/osf.io/bcs73

Kurniawan, D. A., \& Kriestanto, D. (2016). (Kurniawan \& Kriestanto, 2006). $1(1), 19-23$.

Lubis, A. (2007). (Lubis, 2007). Jurnal Ekonomi Dan Keuangan, 1(4), 27-37.

Marlius, D., \& Pebriyana, S. (2020). Analisis Rasio Profitabilitas Pada Pt. Bank Pembangunan Daerah Sumatera Barat Cabang Utama Padang. https://doi.org/10.31219/osf.io/7gnd5

Marlius, D., \& M. (2020). Analisis Rasio Profitabilitas Pada Pt. Bank Pembangunan Daerah Sumatera Barat Cabang Pembantu Rsup Dr. M. Djamil Padang. https://doi.org/10.31219/osf.io/9nrc7

Marlius, D., \& N. (2020). Aktivitas Pemasaran Tabungan Pada Pt. Bank Pembangunan Daerah Sumatera Barat Cabang Pembantu Tarusan. https://doi.org/10.31219/osf.io/fvqc7

Mustika, S., \& Marlius, D. (2019). Analisa Tingkat Kesehatan Keuangan PT. Bank Perkreditan Rakyat (BPR) Batang Palangki. https://doi.org/10.31219/osf.io/wupyh

Marlius, D., \& Ilhami, S. (2020). Analisis Ratio Profitabilitas Pada Pt. Bank Perkreditan Rakyat Jorong Kampung Tangah Pariaman. https://doi.org/10.31219/osf.io/f9gau

Marlius, D., \& Sukma, J. (2020). Analisis Tingkat Kesehatan Bank Pt. Bank Perkreditan Rakyat Jorong Kampung Tangah Pariaman Cabang Padang. https://doi.org/10.31219/osf.io/dmjy5 
Putri, D. M., \& Marlius, D. (2020). Analisis Rasio Profitabilitas Pada Pt. Bank Perkreditan Rakyat Lugas Dana Mandiri Padang. https://doi.org/10.31219/osf.io/kaw2e

Sari, Y. P., \& Marlius, D. (2019). Analisis Rasio Profitabilitas Pada PT. Bank Negara Indonesia Syariah. https://doi.org/10.31219/osf.io/94bwq

Savitri, O. A. (2014). Kredit Bermasalah Pada Kredit Usaha Rakyat ( Studi pada Bank Jatim Cabang Mojokerto ). 12(1), 1-10.

Spica, L., \& Herdinigtyas, W. (2002). ANALISIS RASIO CAMEL TERHADAP PREDIKSI KONDISI BERMASALAH PADA LEMBAGA PERBANKAN PERIODA 2000-2002. November 1997, 131-147.

Vernida, M., \& Marlius, D. (2020). Analisis Rasio Profitabilitas Pada Pt. Bank Perkreditan Rakyat Cempaka Mitra Nagari Padang. https://doi.org/10.31219/osf.io/6usfx 